\title{
Barriers for the Gospel, Confidence in God
}

Back in 1985, Lesslie Newbigin posed the question: 'Can the West be converted? Or is a remorseless decline in Christian faith to the point of extinction inevitable?'203 He dedicated the latter years of his life to exploring what an effective missionary encounter with European culture would mean. Combining practical urban church ministry in Birmingham and missiological reflection, he worked to gain more insight into the needed context for the witness and service of the church on our continent.204 'Here,' he said, 'without possibility of question, is the most challenging missionary frontier of our time.' 205

When Newbigin talked about the West, he really meant Europe, or Western Europe to be precise, for this was the context in which he worked and reflected on the way to communicate the Gospel. He called it a pluralist society. We have called it a multicultural, secularised society with various religious minorities (see chapter 9).

Nowadays, it is commonplace to include Europe in a larger socio-cultural and political context called 'the West.' Viewed from this perspective, there would not seem to be a need to single out Europe as a special subject of analysis. One is tempted to apply the same approaches that are used for other western societies. Quite often, this is what happens. Strategies to evangelise un-churched North Americans are too easily transferred to Germany, Austria, Greece or Spain, on the assumption that un-churched people are alike everywhere in the western world. The success of such ventures is limited to those situations where people closely share a North American mindset. In other situations, such efforts bear no fruit. This alone is sufficient evidence that we are dealing with different contexts.

Communicating the Gospel in this part of the world is not just a matter of applying the general theology of Christian mission. We cannot satisfy ourselves with adopting approaches that have proven to be successful in other countries with similar western cultures. Many who try to do this experience the same discouraging results: for some reason or another, things work differently over here.

203 Lesslie Newbigin, 'Can the West Be Converted?' p. 7ff.

204 As an outcome of this reflexion, Lesslie Newbigin published Foolishness to the Greeks in 1986, and The Gospel in a Pluralist Society in 1989.

205 Leslie Newbigin, 'Can the West Be Converted?' op. cit., p. 7. 


\subsection{A Specific Context for the Communication of the Gospel}

Newbigin was right; there is a need to relate mission theory to Europe as a specific context for the communication of the Gospel. In recent years, the discussion about a contextual approach to mission in Europe is emerging. Despite the importance of this subject, publications from an Evangelical perspective are still relatively rare. Even so, a few inspiring publications are worth noticing.

The South African mission theologian, David Bosch, whose Transforming Mission (1991) is one of the most influential books in missiology today, recognised that he had not sufficiently dealt with the challenge of missiology in the context of western culture. Setting himself this task, he wrote A Missiology of Western Culture, published posthumously. ${ }^{206}$ In order to communicate the Gospel in the European context, he argued, we need to recover the missionary nature of the church and theology. Furthermore, we need to rethink the proper way to engage public life; be open to what churches elsewhere can teach us about missionary experience; reflect on authentic ways of speaking of God; and challenge the so-called autonomy of human reason, this key element of western secularised culture.

In the United Kingdom, Stuart Murray has written about the challenge of evangelism in a post-Christendom society, from an Anabaptist perspective. Instead of lamenting the fact that Christians have become a minority, he says, we should embrace this marginality and discover fresh ways of being church and engaging in mission. ${ }^{207}$ In France, Hansjörg Gantenbein, has developed a model for mission in Europe, based on his analysis of four countries in particular (United Kingdom, France, the eastern part of Germany and Romania).208 On the other side of the Rhine, Friedemann Walldorf has published a comparative study of the different theological approaches to mission in Europe that have been developed in Roman Catholic, ecumenical Protestant and Evangelical circles. ${ }^{209}$ This work prompted the Arbeitskreis für evangelikale Missiologie in Germany to hold a colloquium and produce a publication on the communication of the Gospel in a postmodern European context..10

206 David Bosch, Believing in the Future.

207 Stuart Murray, Post-Christendom.

208 Hansjörg Gantenbein, Mission en Europe.

209 Friedemann Walldorf, Die Neuevangelisierung Europas.

210 Klaus W. Müller (ed.), Mission im postmodernen Europa. 


\subsection{Barriers}

We join this 'conversation' in all modesty, by identifying some typical European barriers to the communication of the Gospel. They are directly related to our analysis in the preceding chapter. Here is the first one:

\section{Why God, or why religion?}

The widespread secularisation of European societies partly explains why models of evangelism that have worked well in Latin America or in Africa do not yield much fruit in Europe. In those parts of the world, the Gospel is communicated among people with some kind of religion: Roman Catholic, animistic or other. As they accept the Evangelical message, they remain religious. They already believed in God, or at least in a divine reality. For them, the cosmos is inhabited by spirits and supernatural beings. They don't have to change this religious worldview in order to accept the Gospel and become Christian. What changes for them, is their image of God, their doctrinal convictions, their religious practices and their spiritual experience. Perhaps they only change denominational attachment. At any rate, they do not change their worldview on a fundamental level; it remains religious.

For secularised people in Europe, the situation is radically difficult. Accepting the invitation of the Gospel implies that they become religious, that their secular worldview is transformed into a religious one. Obviously, this is an additional obstacle. The question is not, which God, what religion? But why God, why religion in the first place? Does God exist? What does 'God' mean? Are you talking about a force, a person, an idea, a projection of a human father figure? Can we experience this God? And if so, why is this important? What is the relevance of religion any way? When I'm not poor, depressed, lonely, ill, or jobless, what would I need a religion for? What does this 'God' add to my life? This set of questions constitutes the first evangelism frontier in Europe.

There is another side to secularisation: it has replaced the religious practice of Christianity. To be precise, secularisation is the secularisation of Christianity. That implies that some Christian elements are retained, such as the idea of the intrinsic value of man, ideas of individual responsibility and freedom, social and cultural values. Secularisation is 'post-Christian,' but only in a partial manner. It takes over the humanist values but detaches them from their original religious context. This results in secular humanism. Secularised people don't see the need to return to a religious worldview in order to work for a better world. The general feeling is that 'we can manage without.'

A striking example is the recent book by the French philosopher and former government minister of education Luc Ferry, entitled 'The Revolution of Love.' In it, he develops what he calls a 'secular spirituality.' based on the Biblical concept of love. He thinks highly of Jesus, 'the supreme example of an altruistic lifestyle.' 
He takes serious the teachings of the church on how to live the commandment to love your neighbour, and summarizes it in the principles of solidarity, the primacy of the common interest, and the value of selfless service. But he confesses to be an agnostic, almost convinced that the God of the Bible is a human creation. In the past, people needed this imagined divine being, he argues, but 'we have to do without, and we can do without.' According to Luc Ferry, 'we have to move on from the humanism of the Enlightenment and its critics, move on from the antireligious stance of thinkers like Nietzsche, and develop a new spirituality: the sacralisation of humanity by practicing the originally Christian principle of love.'211

Viewed from such a perspective, secularisation is a stage that comes after Christianity. What is the next step? There is no next step, at least not a religious one, because secular humanism considers itself to have advanced beyond all religions. For a secularised European to become Christian really amounts to a conversion in the true sense of the word, a complete turnaround in direction. From the point of view of secular humanism, it goes against the thrust of the historical intellectual development of a whole continent! Embracing a religion, even Christianity is seen as a backward step. If this is how secularised people feel about 'becoming religious' or 'adopting a religion,' than it constitutes a formidable barrier for the communication of the Gospel.

One might object that the picture is not as grim as this. Aren't there growing churches everywhere in Europe? Indeed, there are. But a closer look reveals that they are not as successful in reaching secularised fellow citizens as one might think. Their message and their mode of church life elicit more response among nominal Christians who occasionally attend church, and among members of mainline Protestant and Roman Catholic churches, in other words, among people familiar with Christianity, among people with a religious worldview. This is the 'pool' where they 'fish' most successfully. As far as we can see, the majority of people joining an Evangelical church already had some religious beliefs. We don't say this in order to criticize these churches, but only to indicate how difficult it is for the same message to find a hearing among really secularised people.

\section{Why Jesus?}

Once the barrier 'why God?' is overcome, we are confronted with a second one: 'why Jesus?' If someone is interested in Christian spirituality, he will find it fair enough that Jesus be placed in the centre. But is this necessary for everybody

211 Luc Ferry, La révolution de l'amour-Pour une spiritualitélä̈que, p. 7 ff. The typical French word laïque has a specific meaning in France, for which there is no English equivalent. It can refer to the neutrality of the state, to the secular or non-religious character of the public sphere, and to the secular or non-confessional form of education. Ferry uses it in the wider sense of secular life, both public and private. 
who seeks God? Isn't it sufficient that each one has his or her experience of the divine reality? If someone finds Jewish tradition more attractive, why isn't that an equally valid option?

Europeans steeped in a pluralist mindset have difficulty with a message that calls for faith in God and in Jesus Christ as his Son, while excluding all other religions present in the multicultural society. Moreover, any claim to absolute truth or universal value runs counter to a postmodern posture.

Evangelists from other continents will find that people in Europe are so critical, so suspicious. They are not quickly convinced by a miracle. While short summaries of the Gospel in the form of a few clear cut statements might work in other contexts, most Europeans are not ready to accept any clear cut message demanding a simple yes or no for an answer. Through their education they have learned that religious matters are more complex than that. Multicultural society presents them with various religious experiences. According to their European value system they should be tolerant rather than try to impose one religious point of view. They might well be interested in spiritual questions about the meaning of life, they might be willing to take into account religious answers, but they are hesitant to respond when Jesus is presented to them as the unique way to find the truth about our human existence.

To this we should add another factor. The question 'why Jesus' is not the same when it is asked in Europe as opposed to other regions of the world where Christianity is a relatively young religion, or a new religion altogether. In Europe, the name of Jesus is associated with a long history of the church, including the negative aspects of Christianity's record. At secondary school, teenagers learn about the crusades, the wars between Catholics and Protestants, the persecution of the Jews, the abuses of power in the name of Christianity.

However, most people are only superficially familiar with the person of Jesus. From what they know, they will have a positive impression of his ethical conduct, but Christian faith in Jesus the Saviour is quickly associated with the institutional church in their country, which enjoys a far less positive reputation! This creates a huge barrier for presenting Jesus as the Bible presents him. As messengers of the Gospel we have a lot to explain, in Europe more than anywhere else!

Furthermore, many people put Jesus in the box of a particular form of Christianity that has dominated their country. More often than not, they have a negative picture. Dutch people associate believing in Jesus with what they call 'Calvinism': a list of do's and don't's, strict Sunday observance and boring church services with long sermons. French people associate Jesus with the little Christmas baby, the child in the arms of a Madonna, the sculpted figure on a crucifix, and going through the motions of a dull mass ritual. Similar stereotypes exist in every other country. As people associate the Christian faith with such preconceived ideas, they are hindered from taking a fresh look at Jesus. How shall they discover Jesus in a fresh way, as they have never seen him before? 
Why church?

Once passed the first and second barriers, a third one rises before our eyes: 'why church?' Remember, Europe is post-Constantinian. In the past, church membership was self-evident and an obligation. People had no choice. There was no salvation outside the church, said the theologians. In addition, outside the church there was no acceptance, no marriage, no civil service, no school, and no Christian burial.

This has left deep traces in the mind of Europeans, even today. Becoming a church member is associated with obligations. A service to go to every Sunday, money to give, doctrines to believe, rules to obey, not to forget the things you shouldn't do. People like to be allowed the freedom to choose their activities, to decide for themselves.

Today, Europeans are free from such constraints. Church membership is no longer expected. It is no longer a must, no longer a matter of social respectability, but an option. Surely, there are still many nominal church members. In some cases, they are under social pressure from family members to become active members, but strictly speaking, they are under no obligation to attend a service, or even to remain registered. So why should people join a churches if they don't like to commit themselves to all the obligations that go with it? Why can't we pray to God at home, they say, why can't we just follow the ethical principles of Jesus in daily life?

We should add an important point. In non-European countries, churches have to attract members on a voluntary basis. Over there, church is something you decide to participate in. If you don't want to belong to a particular church any longer, you go to another one. This explains why Europeans relate differently to church commitment than Americans, for example.

This also explains why in post-Constantinian Europe, free churches of the Pentecostal and Evangelical type are doing better than historic churches in attracting new members. They have always had to reach out to people in order to arouse their interest.

But these churches are also at a disadvantage because of their view of church life. Emphasising that Christians should live as committed disciples of Jesus, they insist on the minimum requirement of attending the weekly Sunday service. Moreover, there are Bible studies, home groups and prayer meetings to attend, evangelistic activities to participate in, and youth groups and worship teams to volunteer for. Besides, people are strongly encouraged to pray and read the Bible every day if they want to grow in the faith. And of course, there are the moral principles to live by. These expectations are quite demanding when one compares them to the freedom offered by a permissive society, especially in the areas of living as a common-law couple and sexuality.

Of course, Evangelical churches will not present these 'obligations' as a burden, but individual believers might experience them in that way. This is not very attractive for people who have bad memories of church in the past. 
In a post-Constantinian society, church membership is no longer assumed. This fosters the privatisation of religion. Faith in Jesus Christ is not necessarily linked to membership of a religious institution: the famous 'believing without belonging.' It also fosters the 'behaving without belonging' attitude; people are willing to put Christian principles in practice, but not necessarily in the context of a faith community.

Apparently, these attitudes are also making inroads in Christian assemblies known for the level of commitment of their members: traditional Protestant, Pentecostal, Evangelical, Baptist, Adventist and so on. There is a tendency towards 'behaving and believing without too much belonging.' This shows that the 'belonging' side of Christianity is no longer self-evident, even for people who believe in Jesus.

\section{What is new?}

Then there is a fourth barrier. In post-evangelised Europe, the Gospel is not easily presented as good news. The Bible, the church, God, the stories of Jesus and apostles, all of this has become part of our cultural heritage. When people hear about it, their first and automatic reaction is, 'we know all that.' The problem is that they only think they do, but that doesn't change their reaction. The Gospel has been around for ages. So how can it still surprise? How can it be heard as good news? Certainly, people need to hear it as something 'new' in order to be willing to change their mind. Presuppositions are much harder to correct than ignorance. When it comes to the message of the church, preconceived ideas and traditional misrepresentations abound. These images usually put off people rather than attract them to the Gospel. We are faced with widespread indifference; so many people simply don't seem to be interested in God and religion at all.

How can we change these images and preconceived ideas? How can we arouse curiosity for something that will be 'new' to many Europeans, namely a living faith relationship with God?

\subsection{Confidence}

Clearly, there are formidable obstacles to making our faith convictions understood. What is our attitude as believers in Jesus Christ in the socio-religious situation of Europe today? When we look to the future, we can share the uncertainty of those who observe phenomena and trends. Humanly speaking, Christianity does not seem to be in for a massive comeback in the short run. But as believers we have something else to go by. We do not know what the future holds, but we know Him who holds the future, and who is more than capable of creating surprises in societies bent on further de-Christianisation and secularisation. 
Granted, there are many barriers that hinder our fellow citizens from hearing the Gospel as good news instead of an old-time and obsolete religion, but we can have confidence that the Word of God is able to create for itself a new hearing, time and time again. In the final analysis, the task depends not on our arguments, not even on our apologetics, as well developed and attuned to the modern mind as they may be, but on the Spirit of God. He convinces hearts and minds. The same Spirit can make us creative in finding ways to overcome the obstacles, to identify bridges for the message, to make a positive contribution to society, to present Biblical truth in eye-opening ways.

In his book The Gospel in a Pluralist Society, Lesslie Newbigin deals with the question how to present truth, and how to live according to the conviction of truth, in a multicultural, secularised and postmodern society. As the church will continue to shrink and become a minority, it is called to testify, as a minority, to the truth for all humankind.

What Newbigin wrote is still as relevant today as it was in 1989 when he published the book. His concluding remarks about 'confidence in the Gospel' are worth quoting:

The Gospel is news of what has happened. The problem of communicating it in a pluralist society is that it simply disappears into the undifferentiated ocean of information. It represents one opinion among millions of others. It cannot be 'the truth,' since in a pluralist society truth is not one but many. To claim that it is true for everyone is simply arrogance. It is permitted as one opinion among many. Churches have been eager to avoid the charge of arrogance. They have been eloquent in their efforts to distance themselves from what is now judged to have been the arrogance of missionaries who talked of the evangelisation of the world in their generation. ${ }^{212}$

In reaction to this supposed or real arrogance, Newbigin notices that Christians develop different attitudes. One is 'timidity,' an exaggerated modesty to avoid any form of testimony that might offend people of other persuasions.

The other mood is 'anxiety.' Christianity is perceived to be a good cause which is in danger of collapsing through lack of support. Anxiety can lead to activism, 'a strident summons to more energetic efforts in evangelism and social action.' Of course, it is important for Christians to be active in both areas, but this can be an expression of anxiety when there is 'an underlying mood which lays too much stress on our own activities and is too little controlled by the sense of the greatness and majesty and sufficiency of God.'

212 Lesslie Newbigin, The Gospel in a Pluralist Society, p. 242. 
Over and against this kind of Christian activity which only thinly masks a lack of confidence in the sufficiency of God, Newbigin suggests an attitude of 'confidence.' He explains:

In a pluralist society, any confident affirmation of the truth is met by the response; 'Why should I believe this rather than that?' Of course, if it is indeed an ultimate belief, then it cannot be validated by something more ultimate. And if, as always happens in a pluralist society, we are asked: 'But why start with Jesus?' we have to answer that no rational thought is possible except by starting with something which is already given in some human tradition of rational thought and discourse. Our immediate answer may well be, 'Why not?' For the ultimate answer we have to wait for the end of all things.

A Christian must welcome some measure of plurality but reject pluralism. A plural society provides us with a wider range of experience and a wider diversity of human responses to experience, and therefore richer opportunities for testing the sufficiency of our faith than are available in a monochrome society....But we must reject the ideology of pluralism. We must reject the invitation to live in a society where everything is subjective and relative, a society which has abandoned the belief that truth can be known and has settled for a purely subjective view of 'truth for you but not truth for all. ${ }^{213}$

In one of his last publications, Newbigin has further developed this theme of confidence. We need to have the 'right kind of confidence,' he writes, not so much in our methods as in God. Through his Spirit, God brings to life the words of God in men and women, even today. ${ }^{214}$ We can trust Him for that. Our confidence is that God can use the testimony of faithful Christian discipleship to speak to the hearts and minds of our fellow-Europeans.

213 Idem, p. 244.

214 Lesslie Newbigin, Proper Confidence (1995). 
